\title{
Profiling of phenolic compounds and their antioxidant and anticancer activities in pandan (Pandanus amaryllifolius Roxb.) extracts from different locations of Malaysia
}

\author{
Ali Ghasemzadeh ${ }^{*}$ and Hawa ZE Jaafar
}

\begin{abstract}
Background: Phytochemicals and antioxidants from plant sources are of increasing interest to consumers because of their roles in the maintenance of human health. Most of the secondary metabolites of herbs are used in a number of pharmaceutical products.

Methods: Secondary metabolites composition and content of five flavonoids and three phenolic acids were evaluated and determined in Pandanus amaryllifolius extracts from three different locations of Malaysia by RP-HPLC; Total phenolic and total flavonoid content were determined using Folin-Ciocalteau and aluminum chloride colorimetric assay; The antioxidant activity of the extracts was determined by the ferric reducing antioxidant potential (FRAP) assay and 1,1-diphenyl-2-picrylhydrazyl (DPPH) assays. MTT (3-(4,5-Dimethylthiazol-2-yl)-2,5-diphenyltetrazolium bromide) Assay was employed to screen anticancer activity of extracts against MCF-7 cancer cell line.

Results: Highest value of total flavonoids (TF) and total phenolics (TP) was observed in pandan extract from Bachok locattion (1.87 mg/g DW and $6.72 \mathrm{mg} / \mathrm{g}$ DW) followed by Klang $(1.32 \mathrm{mg} / \mathrm{g} \mathrm{DW} ; 5.07 \mathrm{mg} / \mathrm{g}$ DW) and Pontian $(1.12 \mathrm{mg} / \mathrm{g}$ DW; $4.88 \mathrm{mg} / \mathrm{g}$ DW). Rutin just detected from Bachok location with value of $0.082 \mathrm{mg} / \mathrm{g}$ DW. High content of epicatechin $(0.035 \mathrm{mg} / \mathrm{g} \mathrm{DW})$ and naringin $(0.325 \mathrm{mg} / \mathrm{g}$ DW) were observed from Bachok location while, highest content of catechin $(0.613 \mathrm{mg} / \mathrm{g}$ DW) and kaempferol $(0.278 \mathrm{mg} / \mathrm{g}$ DW $)$ was observed in pandan extract from Klang location. The extract of pandan from Bachok exhibited highest value of gallic acid ( $0.423 \mathrm{mg} / \mathrm{g} \mathrm{DW}$ ) and cinnamic acid $(0.084 \mathrm{mg} / \mathrm{g}$ DW). Ferrulic acid just detected from pandan extract of Bachok location with concentration of $0.281 \mathrm{mg} / \mathrm{g}$ DW. Between studied locations Bachok exhibited highest value of DPPH (64.27\%) and FRAP $(517.2 \mu \mathrm{m}$ of Fe (II)/g) activity followed by Klang (52.16\%; $448.6 \mu \mathrm{m}$ of Fe (II)/g) and Pontian $(50.10 \% ; 314.8 \mu \mathrm{m}$ of Fe (II)/g). The preliminary screening showed pandan extracts from 3 locations possessed anticancer promoting activity against MCF-7 cell line, with 78.3\%, 70.5\% and 67.4\% inhibition rate, respectively. Maximum MCF-7cell line inhibition was observed in pandan extract from Bachok location.
\end{abstract}

Conclusions: The samples collected from the North (Bachok) exhibited the highest TP, TF antioxidant and anticancer activity while those from the Southern portion (Pontian) appeared to have the lowest content of TP, TF and antioxidant activity.

Keywords: Pandanus amaryllifolius, Flavonoids, HPLC, Antioxidant activity, DPPH, FRAP, Anticancer activity, MCF-7

\footnotetext{
* Correspondence: alighasemzadeh@upm.edu.my; Hawazej@upm.edu.my

Department of Crop Science, Faculty of Agriculture, University Putra Malaysia, 43400 Serdang, Selangor, Malaysia
}

\section{Biomed Central}




\section{Background}

Most plants are major sources of natural products used in pharmaceuticals, agrochemicals, flavour and fragrance ingredients, food additives, and pesticides. Secondary compounds are unique to a species or group, and they are important for defense, protection and competition [1]. Most of these compounds are commonly used as flavourings, medicines, or recreational drugs. Secondary chemicals are important in plant use by humans. Most pharmaceuticals are based on plant component structures, and secondary metabolites are widely used especially in Asia [2]. Phenolic compounds are famous group of secondary metabolites with wide pharmacological activities. Flavonoids are an important group of secondary metabolites and are a source of bioactive compounds in plants [3]. They are also a kind of natural product with antioxidant properties capable of scavenging free superoxide radicals, having anti-aging properties as well as reducing the risk of cancer. Park et al. [4] showed that some flavonoid components in green tea are effective in inhibiting cancer or induce mechanisms that may kill cancer cells and inhibit tumor invasion. It was found that flavonoids reduced blood-lipids and glucose, and enhanced human immunity $[5,6]$. The effect of flavonoids on human health is the result of their ability to induce human protective enzyme systems [7]. Several studies have suggested that flavonoids such as catechin and rutin are able to control cancer cell growth in the human body [8-10].

Pandan (Pandanus amaryllifolius Roxb.) is a tropical plant of the family Pandanaceae in the screw pine genus. Pandan leaf, often known as screw pine, because they resemble the pineapple with the spiral arrangement of long, narrow and strap-shaped green leaves [11]. Even though the Pandanaceae family comprises approximately 600 species, there are only Pandanus amaryllifolius Roxb. and Pandanus odoratissimus Linn. that have fragrant leaves and flowers, respectively [12]. The genus Pandanus from the family Pandanaceae comprises approximately 600 species that are widely distributed in tropical and subtropical regions. The sweet and delightful flavour of pandan leaves, which is well-known as a source of natural flavouring, is widely used in various parts of South-East Asian countries including India, Thailand, Indonesia and Malaysia. For example, pandan leaves are commonly used when preparing rice dishes as a means of enhancing flavour. In addition, pandan leaves are also used in making other food, such as desserts, sweets, coconut jam and ice cream. Due to the high chlorophyll content, pandan leaves are also a popular green colourant for food [13]. In Malaysia, herbs and spices are generally eaten raw and fresh as vegetable (salad), especially among the Malay community. Most of these herbs and spice are believed to be associated with high antioxidant activities and have many benefits on human body. A systematic search for anticancer plants began in the middle of the $21^{\text {th }}$ century through the applications of appropriate biological screening assays. The chemopreventive properties of plants extracts are often investigated via screening against a panel of human cancer cell lines. In recent years, there has been increasing interest in organically grown food because people believe that they have less pesticide residues and are healthier [14]. However, most studies on this subject have reported conflicting results and it is unclear whether or not organically grown food contains more health-promoting phytochemicals as opposed to conventionally grown food. Information about flavonoid compounds of Malaysian pandan and their antioxidant and anticancer activity are still scarce and some information and such data would be useful to provide information on foods containing high levels of beneficial components. The present investigation was undertaken to screen phytochemical potential and their antioxidant activities in $P$. amaryllifolius collected from three different location of Malaysia. In addition in vitro anticancer properties of the extracts against breast cancer cell lines were also investigated.

\section{Methods}

\section{Plant material and maintenance}

Fresh leaves of $P$. amaryllifolius were collected locally from three different province of Malaysia namely: Johor (pontian, south), Selangor (Klang, Central) and Kelantan (Bachok, North). The samples were identified by Malaysian Agriculture Research and Development Institute (MARDI). Voucher specimens of $P$. amaryllifolius Kelantan (MTP008/1), Selangor (MTP008/2) and Johor (MTP008/3) were collected. Malaysian Agriculture Research and Development Institute (MARDI) verified and kept samples. The leaves were shade dried and were powdered using mechanical grinder. This powered material is used for further analysis.

\section{Preparation of flavonoids extract}

Leaf samples $(0.25 \mathrm{~g})$ were extracted with $20 \mathrm{~mL}$ of methanol on a shaker for $2 \mathrm{~h}$ at room temperature. The extract solution was treated with $6 \mathrm{M} \mathrm{HCl}(5 \mathrm{ml})$ and refluxed at $90^{\circ} \mathrm{C}$ for $2 \mathrm{~h}$. The hydrolysed sample was cooled to room temperature and filtered through a $0.45 \mu \mathrm{m}$ membrane [15].

\section{Determination of total flavonoids}

The TF were measured following a previously reported spectrophotometric method [16]. Briefly, extracts of each plant material $(1 \mathrm{~mL})$ were diluted with $4 \mathrm{~mL}$ water in a $10 \mathrm{~mL}$ volumetric flask. Initially, $5 \% \mathrm{NaNO}_{2}$ solution $(0.3 \mathrm{~mL})$ was added to each volumetric flask; after $5 \mathrm{~min}, 10 \% \mathrm{AlCl}_{3}(\mathrm{w} / \mathrm{v})$ was added; and at $6 \mathrm{~min}, 1.0 \mathrm{M}$ 
$\mathrm{NaOH}(2 \mathrm{~mL})$ was added. Absorbance of the reaction mixture was read at $430 \mathrm{~nm}$.

\section{Separation and analysis of flavonoids by HPLC}

Reversed-phase HPLC was used to assay flavonoid composition. The Agilent HPLC system used consisted of a Model 1100 pump equipped with a multi-solvent delivery system, an L-7400 ultraviolet (UV) detector, and fitted with an Agilent C18 $(5 \mu \mathrm{m}, 4.6 \times 250 \mathrm{~mm})$ column. The mobile phase consisted of: (A) $2 \%$ acetic acid $\left(\mathrm{CH}_{3} \mathrm{COOH}\right)$ and (B) $0.5 \%$ acetic acid-acetonitrile $\left(\mathrm{CH}_{3} \mathrm{CN}\right),(50: 50 \mathrm{v} / \mathrm{v})$. The mobile phase was filtered under vacuum through a 0.45 um membrane filter before use. Gradient elution was performed as follows: $0 \mathrm{~min}, 95: 5 ; 10 \mathrm{~min}, 90: 10$; $40 \mathrm{~min}, 60: 40$, $55 \mathrm{~min}, 45: 55$; $60 \mathrm{~min}, 20: 80$; and $65 \mathrm{~min}$, $0: 100$. The flow rate was maintained at $1 \mathrm{~mL} / \mathrm{min}$ and UV absorbance was measured at $260-360 \mathrm{~nm}$. The operating temperature was maintained at room temperature [17]. Identification of the flavonoids was achieved by comparison of retention times with standards, UV spectra and UV absorbance ratios after co-injection of samples and standards. The standards $[(+)$-Catechin, (-)-Epicatechin, Naringin, Rutin and Kaempferol] were purchased from Sigma-Aldrich (St. Louis, MO, USA).

\section{Preparation of phenolic acids extract}

Phenolics extracts were prepared by first carefully pipetting phosphoric acid $\left(\mathrm{H}_{3} \mathrm{PO}_{4}, 1.2 \mathrm{~mL}\right)$ into about $950 \mathrm{~mL}$ water in a $1 \mathrm{~L}$ volumetric flask, mixing and bringing to volume with water. Then leaves $(0.25 \mathrm{~g})$ were extracted with $20 \mathrm{~mL}$, of this phosphoric acid solution. Five $\mathrm{mL}$ of $6 \mathrm{M} \mathrm{HC1}$ was added to each extract to give a $25 \mathrm{~mL}$ solution of $1.2 \mathrm{M}$ $\mathrm{HC} 1$ in $50 \% \mathrm{MeOH}$. Extracts were refluxed at $90^{\circ} \mathrm{C}$ for $2 \mathrm{~h}$ and solution was filtered through a $0.45 \mu \mathrm{m}$ filter [18].

\section{Determination of total phenolic content}

The total phenolic content was determined following the method of Kim et al. [19]. Briefly, $1 \mathrm{~mL}$ of extract was added to deionized water $(10 \mathrm{~mL})$ and Folin-Ciocalteu phenol reagents $(1.0 \mathrm{~mL})$. After $5 \mathrm{~min}, 20 \%$ sodium carbonate $(2.0 \mathrm{~mL})$ was added to the mixture. The solution was kept in total darkness, and the absorbance was measured at $750 \mathrm{~nm}$ using a spectrophotometer (U-2001, Hitachi Instruments Inc., Tokyo, Japan).

\section{Separation and analysis of phenolic acids by HPLC}

An Agilent HPLC system (Tokyo, Japan) consisting of a Model 1100 pump equipped with a multisolvent delivery system and a L-7400 ultraviolet (UV) detector was used. The column was an Agilent C18 $(5 \mu \mathrm{m}, 4.6 \times 250 \mathrm{~mm})$. The mobile phase was composed of phosphoric acid (aqueous) and (B) acetonitrile and gradient elution was performed as follows: $0 \mathrm{~min}, 85: 15 ; 12 \mathrm{~min}, 75: 25$; $20 \mathrm{~min}, 75: 25 ; 22 \mathrm{~min}, 85: 15$ and $30 \mathrm{~min}, 85: 15$. The mobile phase was filtered under vacuum through a $0.45 \mathrm{~lm}$ membrane filter before use. The flow rate and injection volume were $1 \mathrm{~mL} / \mathrm{min}$ and $20 \mu \mathrm{L}$. UV absorbance was measured at $220-360 \mathrm{~nm}$. The operating temperature was maintained at room temperature [18]. Identification of the phenolic acids were achieved by comparison with retention times of standards, UV spectra and calculation of UV absorbance ratios after co-injection of samples and standards. Commercial standards [Gallic acid, trans-Cinnamic acid and trans-Ferulic acid] were purchased from Sigma-Aldrich.

\section{Determination of antioxidant activity \\ Ferric reducing antioxidant potential (FRAP) assay}

The stock solutions consisted of $300 \mathrm{mM}$ acetate buffer, $10 \mathrm{mM}$ TPTZ (2,4,6-tripyridyl-S-triazine) solution in $40 \mathrm{mM} \mathrm{HCl}$, and $20 \mathrm{mM} \mathrm{FeCl}_{3}$ solution. Acetate buffer $(25 \mathrm{~mL})$ and TPTZ $(2.5 \mathrm{~mL})$ were mixed, and $2.5 \mathrm{~mL}$ $\mathrm{FeCl}_{3}$ added. Leaf extract $(150 \mu \mathrm{L})$ was added to $2850 \mu \mathrm{L}$ of the FRAP solution and kept for $30 \mathrm{~min}$ in the dark place. The absorbance of solution was measured at $593 \mathrm{~nm}$ using a spectrophotometer (U-2001, Hitachi Instruments Inc., Tokyo, Japan) [20].

\section{1,1-Diphenyl-2-picrylhydrazyl (DPPH) assay}

1,1-Diphenyl-2-picrylhydrazyl (DPPH) was purchased from Sigma-Aldrich. Butylated hydroxytoluene (BHT) and $\alpha$-tocopherol were purchased from Merck. The radical scavenging ability was determined using the method described in Mensor et al. [21]. Briefly, an alcohol solution of DPPH ( $1 \mathrm{~mL}, 3 \mathrm{mg} / \mathrm{mL})$ was added to $2.5 \mathrm{~mL}$ samples containing different concentrations of extracts. The samples were first kept in the dark at room temperature and their absorbance was read at $518 \mathrm{~nm}$ after $30 \mathrm{~min}$. The antiradical activity was determined using the following formula:

$$
\begin{aligned}
& \text { Percent }(\%) \text { inhibition of DPPH activity } \\
& \quad=\left[\left(A_{0}-A_{1}\right) / A_{0}\right] \times 100 \%
\end{aligned}
$$

Where $A_{0}$ is the absorbance value of the blank sample or control reaction, and $A_{1}$ is the absorbance value of the test sample. The optic density of the samples and controls were measured in comparison to ethanol. BHT (butylhydroxytoluene) and Vit C, were used as positive controls.

\section{Determination of anticancer activity Cell culture and treatment}

Human breast carcinoma (MCF-7) and normal (MCF-10A) cells were cultured in $100 \mu \mathrm{L}$ of RPMI 1640 media (Roswell Park Memorial Institute) containing 10\% fetal bovine serum (FBS). MCF-7 cells were incubated overnight at $37^{\circ} \mathrm{C}$ in $5 \%$ $\mathrm{CO}_{2}$ for cell attachment. 


\section{MTT (3-(4,5-Dimethylthiazol-2-yl)-2,5-diphenyltetrazolium bromide) assay}

The assay was conducted as follows: Cancer cells were seeded in 96-well plates at a density of $1 \times 104$ cells/well in $100 \mu \mathrm{L}$ RPMI. At $24 \mathrm{~h}$ after seeding, the medium was removed and the cells were incubated for 3 days with RPMI in the absence or presence of various concentrations of extracts. Extract concentrations used ranged from 20, 40, $80,160,320$ and $640 \mu \mathrm{g} / \mathrm{mL}$. After incubation, $20 \mu \mathrm{L}$ of MTT [3-(4,5-dimethylthiazol-2-yl)-2,5-diphenyltetrazolium bromide] reagent was added into each well. The plate was incubated again for $4 \mathrm{~h}$ in a $\mathrm{CO}_{2}$ incubator at $37^{\circ} \mathrm{C}$. The resulting MTT-products were determined by measuring the absorbance at $570 \mathrm{~nm}$ using ELISA reader [22]. Each point represents the mean of triplicate experiments. The cell viability was determined using the formula:

$$
\begin{aligned}
\text { Viability }(\%) & =(\text { optical density of sample/optical density of control }) \\
& \times 100
\end{aligned}
$$

\section{Statistical analysis}

All analytical values shown represent the means of three replicates. Data were analysed using analysis of variance by Statistical Analysis System (SAS 9.0). Mean separation test between treatments was performed using Duncan multiple range test and a P-value $\leq 0.05$ was regarded as significant.

\section{Results and discussion}

The concentrations of TF and some flavonoid compounds The results obtained from the preliminary analysis of flavonoid compounds are shown in Table 1. There was a significant difference between the three locations for TF production in pandan. Highest value of TF content in pandan was observed in Bachok $(1.87 \pm 0.246 \mathrm{mg} / \mathrm{g} \mathrm{DW})$ location followed by klang $(1.32 \pm 0.211 \mathrm{mg} / \mathrm{g} \mathrm{DW})$ and pontian $(1.12 \pm 0.177 \mathrm{mg} / \mathrm{g} \mathrm{DW})$. In this research, 5 flavonoid compounds were detected and identified

Table 1 The concentrations of TF and some flavonoid compounds detected in pandan extracts from three different locations

\begin{tabular}{llll}
\hline & Bachok & Klang & Pontian \\
\hline TF & $1.87 \pm 0.246^{\mathrm{a}}$ & $1.32 \pm 0.211^{\mathrm{b}}$ & $1.12 \pm 0.177^{\mathrm{c}}$ \\
Rutin & $0.082 \pm 0.028^{\mathrm{a}}$ & $\mathrm{ND}$ & $\mathrm{ND}$ \\
Epicatechin & $0.035 \pm 0.045^{\mathrm{a}}$ & $0.022 \pm 0.039^{\mathrm{a}}$ & $0.008 \pm 0.042^{\mathrm{a}}$ \\
Catechin & $0.527 \pm 0.024^{\mathrm{b}}$ & $0.613 \pm 0.015^{\mathrm{a}}$ & $0.153 \pm 0.046^{\mathrm{c}}$ \\
Kaempferol & $0.158 \pm 0.033^{\mathrm{b}}$ & $0.278 \pm 0.029^{\mathrm{a}}$ & $\mathrm{ND}$ \\
Naringin & $0.325 \pm 0.025^{\mathrm{a}}$ & $0.223 \pm 0.026^{\mathrm{b}}$ & $\mathrm{ND}$
\end{tabular}

All analyses are the mean of triplicate measurements \pm standard deviation. Results expressed in $\mathrm{mg} / \mathrm{g}$ DW. $\mathrm{a}, \mathrm{b}, \mathrm{c}$ represents Duncan multiple range test letters. Means not sharing a common letter were significantly different at $\mathrm{P} \leq 0.05$. ND: not detected. from pandan extract. There was a significant difference $(\mathrm{P} \leq 0.05)$ between the three locations for TF content.

As shown in Table 1, rutin detected just from one locations (Bachok) and high value of this flavonoid was recorded $0.082 \pm 0.028 \mathrm{mg} / \mathrm{g} \mathrm{DW}$. Bachok location also, showed high epicatechin content $(0.035 \pm 0.045 \mathrm{mg} / \mathrm{g} \mathrm{DW})$ compared to Klang location but, there were no significant differences between locations for epicatechin content in pandan extracts. High concentration of catechin was observed in Klang location $(0.613 \pm 0.015 \mathrm{mg} / \mathrm{g} \mathrm{DW})$.

Kaempferol is a rare flavonoid component in plants, but it was detected in the pandan extracts just from two locations (Bachok and Klang) with remarkable concentration. Klang showed highest concentration of kaempferol $(0.278 \pm 0.029 \mathrm{mg} / \mathrm{g} \mathrm{DW})$ followed by Bachok $(0.158 \pm 0.033 \mathrm{mg} / \mathrm{g} \mathrm{DW})$. These kaempferol contents were higher than those recorded in pegaga $(0.0205 \mathrm{mg} / \mathrm{g} \mathrm{DW})$, sengkuang (0.037 mg/g DW), carrot $(0.140 \mathrm{mg} / \mathrm{g} \mathrm{DW})$, green chilli $(0.039 \mathrm{mg} / \mathrm{g} \mathrm{DW})$ and white radish $(0.0383 \mathrm{mg} / \mathrm{g} \mathrm{DW})$ [23]. In other study, Tolonen et al. [24] identified kaempferol in white cabbages with concentration of $0.9 \mathrm{mg} / \mathrm{kg} \mathrm{FW}$, and it was the only flavonoid found. Meanwhile, Kim and Lee [25] detected about 0.1-0.8 mg/g FW of kaempferol contents in green cabbages. In current study kaempferol was not detected in pandan extract from pontian location.

Naringin was also detected from pandan extract with substantial concentration. Between studied locations Bachok showed highest value $0.325 \pm 0.025 \mathrm{mg} / \mathrm{g}$ DW followed by Klang $0.223 \pm 0.026 \mathrm{mg} / \mathrm{g}$ DW. Naringin was not detected from pandan in Pontian location. Zhang et al. [26] identified rutin in pandan (location of Felorida, USA) with concentration of $0.356 \mathrm{mg} / 100 \mathrm{~g}$ DW. Generally, between identified flavonoid compounds the important compound based on concentration from high to low were: catechin $>$ naringin $>$ kaempferol $>$ rutin $>$ epicatechin. Results imply that catechin is abundant flavonoid compounds in pandan. Figure 1 shows the HPLC chromatogram of pandan extracts from Bachok location.

\section{The concentrations of TP and some phenolic acids}

Usually, phenolics that possess antioxidant activity are known to be mainly flavonoids and phenolic acids. Phenolic acids are a major class of phenolic compounds, widely occurring in the plant kingdom especially in herbs and vegetables. As shown in Table 2, pandan extract from Bachok present highest content of TP $(6.72 \pm 0.355 \mathrm{mg} / \mathrm{g} \mathrm{DW})$ followed by Klang $(5.07 \pm$ $0.406 \mathrm{mg} / \mathrm{g} \mathrm{DW})$ and Pontian (4.88 $\pm 0.477 \mathrm{mg} / \mathrm{g} \mathrm{DW})$. A significant difference $(\mathrm{P} \leq 0.05)$ was observed between Bachok and Klang in TP content but, differences between Klang and Pontian was not significant. However, compared to some of potent herbs like as Melisa officinalis (13.2 mg/g DW), Taraxacum officinale (12.6 mg/g DW), Acorus calamus (12.45 mg/g DW), Echinacea purpurea 

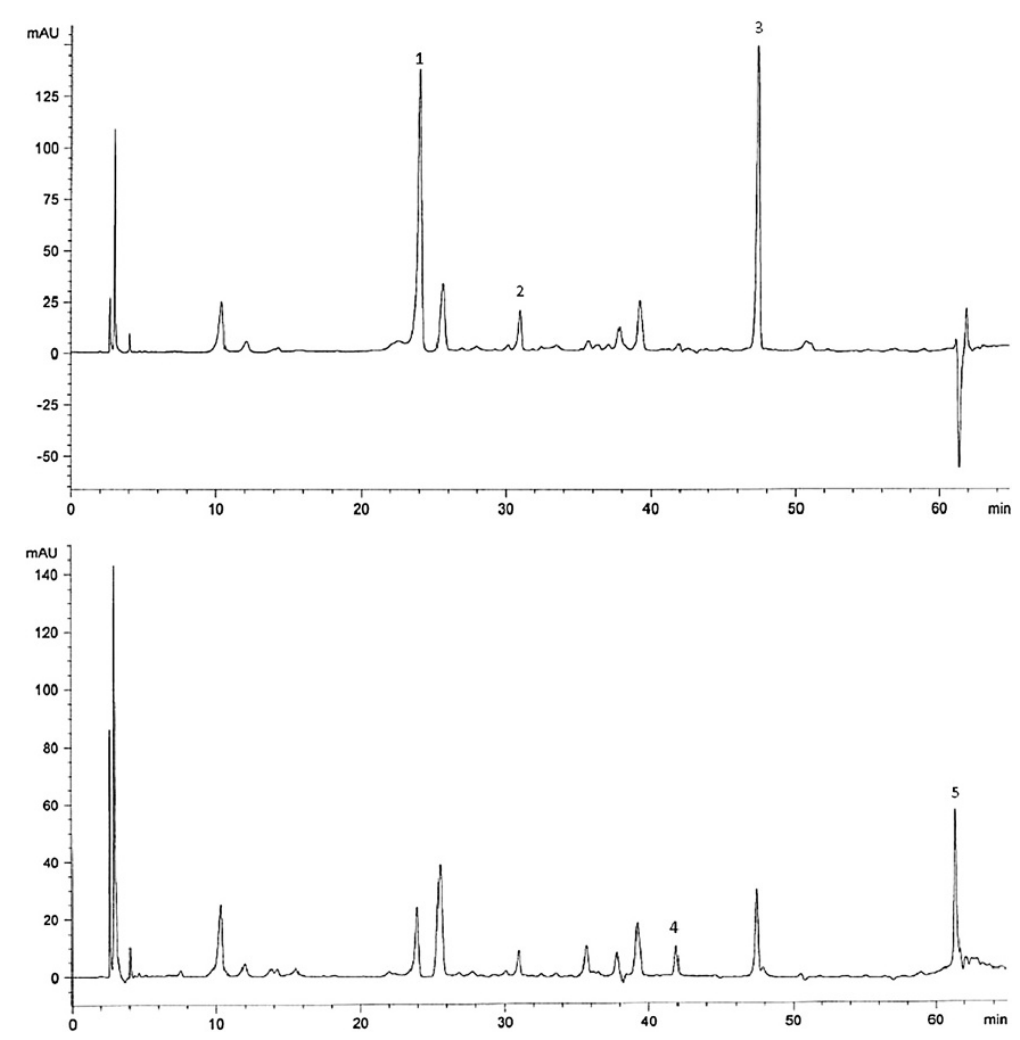

Figure 1 HPLC chromatograms of flavonoid compounds extracted from pandan, Bachok location. The identified peaks are: catechin (1), epicatechin (2), naringin (3), rutin (4) and kaempferol (5).

(15.1 mg/g DW), Syzygium aromaticum (8.96 mg/g DW) and Salvia officinalis $(8.25 \mathrm{mg} / \mathrm{g} \mathrm{DW})$ pandan recorded lowest contents of TP $[27,28]$.

It is evident that the total phenolic content measured by the Folin-Ciocalteu method does not give a full picture of the quality or quantity of the phenolic compounds in the plant extracts [29]. In current research three phenolic acids including gallic acid, cinnamic acid and ferulic acid were identified in pandan extracts from three locations. The extract of pandan from Bachok exhibited highest value $(0.423 \pm 0.052 \mathrm{mg} / \mathrm{g} \mathrm{DW})$ of gallic acid compared to Klang $(0.325 \pm 0.041 \mathrm{mg} / \mathrm{g} \mathrm{DW})$ and Pontian $(0.214 \pm 0.019 \mathrm{mg} / \mathrm{g}$ DW) locations. In addition no significant difference was observed between Klang and Pontian locations for gallic

Table 2 The concentrations of TP and some phenolic acids detected in pandan extracts from three different locations

\begin{tabular}{llll}
\hline & Bachok & Klang & Pontian \\
\hline TP & $6.72 \pm 0.355^{\mathrm{a}}$ & $5.07 \pm 0.406^{\mathrm{b}}$ & $4.88 \pm 0.477^{\mathrm{b}}$ \\
Gallic acid & $0.423 \pm 0.052^{\mathrm{a}}$ & $0.325 \pm 0.041^{\mathrm{a}}$ & $0.214 \pm 0.019^{\mathrm{b}}$ \\
Cinnamic acid & $0.084 \pm 0.033^{\mathrm{a}}$ & $0.033 \pm 0.018^{\mathrm{b}}$ & $\mathrm{ND}$ \\
Ferulic acid & $0.281 \pm 0.037^{\mathrm{a}}$ & $\mathrm{ND}$ & $\mathrm{ND}$ \\
\hline
\end{tabular}

All analyses are the mean of triplicate measurements \pm standard deviation. Results expressed in $\mathrm{mg} / \mathrm{g}$ DW. Means not sharing a common letter were significantly different at $\mathrm{P} \leq 0.05$. acid production in pandan. As Table 2 shows, among the studied phenolic compounds cinamic acid was detected from Bachok and Klang locations. Bachok location represent high value $(0.084 \pm 0.033 \mathrm{mg} / \mathrm{g} \mathrm{DW})$ of cinnamic acid followed by Klang $(0.033 \pm 0.018 \mathrm{mg} / \mathrm{g} \mathrm{DW})$. Cinnamic acid was not detected in pandan extract from Pontian location. Ferulic acid was detected just in pandan extract of Bachok location with value of $0.281 \pm 0.037 \mathrm{mg} / \mathrm{g}$ DW. Ferulic acid was shown to inhibit the photo peroxidation of linoleic acid which is potent fatty acid for decrease cancer risk, improve immune function, diabetes and heart disease prevention [23]. The most interesting finding was that ferulic acid just detected in pandan extracts from Bachok location. However, this result has not previously been described. Results imply that gallic acid is abundant pheolic acid between identified phenolics in pandan extracts.

\section{Antioxidant activity}

\section{Ferric reducing antioxidant potential (FRAP) assay}

The FRAP assay depends upon the reduction of ferric tripyridyltriazine (Fe (III)-TPTZ) complex to the ferrous tripyridyltriazine (Fe (II)-TPTZ) by a reductant at low $\mathrm{pH}$. The FRAP assay has been used widely to estimate the antioxidant component/power in dietary polyphenols [30]. As Figure 2 shows, the reducing power for the pandan 


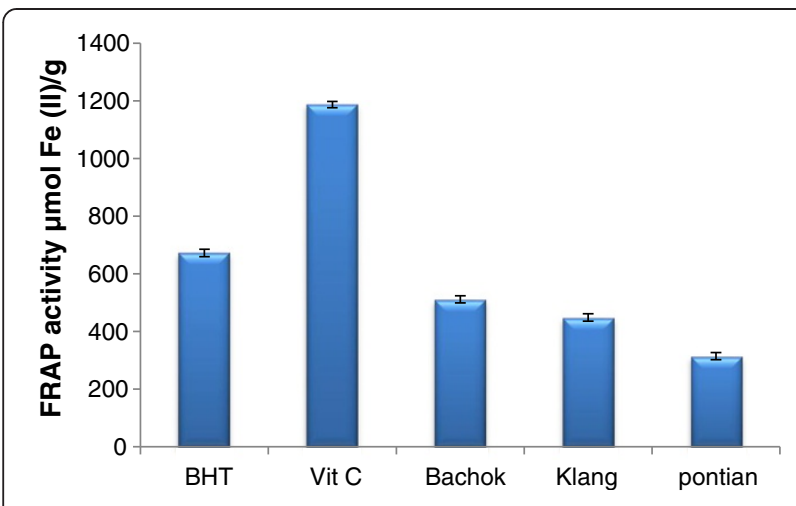

Figure 2 FRAP activity of pandan extracts collected from three different locations compared to the positive controls butylated hydroxytoluene (BHT) and vitamin $\mathrm{C}$.

extracts from three different locations was in the range of 511.2 (Bachok) to $314.8 \mu \mathrm{m}$ of Fe (II)/g (Pontian). The FRAP values for the pandan extract in three locations were significantly lower than those of BHT $(672.4 \mu \mathrm{mol}$ $\mathrm{Fe}(\mathrm{II}) / \mathrm{g})$ and Vit C (1186.55 $\mu \mathrm{mol} \mathrm{Fe}(\mathrm{II}) / \mathrm{g})$. In this study, we used the FRAP assay because it is quick and simple to measure the antioxidant capacity of purpose compounds and not only plants, wines, and animal tissues [31,32]. In general, antioxidant activity of flavonoids belong to the substitution pattern and structure of hydroxyl groups. In flavonoids chemical structure 30,40-orthodihydroxy in ring $\mathrm{B}$ and 4-carbonyl group in ring $\mathrm{C}$ are the fundamental requirement for effective radical scavenging. The presence of 3- and 5-OH groups, giving a catechol-like structure in ring $\mathrm{C}$, is also essential for the antioxidant activity of flavonoid compounds [28]. Furthermore, the presence of the $\mathrm{C} 2-\mathrm{C} 3$ bond configured with a 4-keto arrangement is recognized to be responsible for electron delocalization from ring $\mathrm{B}$ and following that enhance the free radical scavenging activity. In the absence of the o-dihydroxy structure in ring $\mathrm{B}$, a catechol structure in ring $\mathrm{A}$ can compensate for flavonoid antioxidant activity [33].

\section{1,1-Diphenyl-2-picrylhydrazyl (DPPH) assay}

The effect of antioxidants on DPPH scavenging is due to their hydrogen donating ability. Between studied locations Bachok exhibited highest value (64.27\%) of DPPH activity followed by Klang (52.16\%) and Pontian (50.10\%), (Figure 3). In addition, significant difference was observed between three location for DPPH activity. The results of the current study showed that DPPH radical scavenging abilities of the extracts of pandan from three locations were less than those of butylated hydroxytoluene (BHT) $(83.7 \%)$ and Vit $C(92.3 \%)$ at $35 \mathrm{mg} / \mathrm{mL}$. The $\mathrm{IC}_{50}$ (fifty percent free radical scavenging) value of pandan extract were 9.25, 11.6 and $12.5 \mathrm{mg} / \mathrm{mL}$ for Bachok, Klang and Pontian locations respectively. Sasikumar et al. [34]

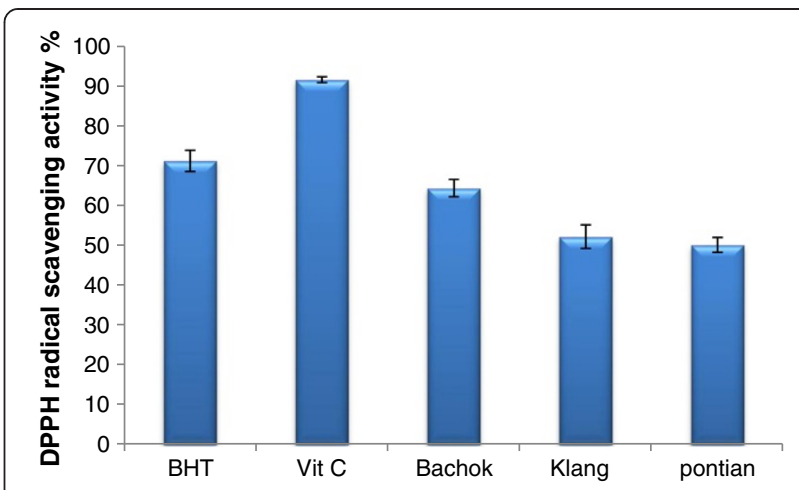

Figure 3 DPPH radical scavenging activity of pandan extracts collected from three different locations compared to the positive controls butylated hydroxytoluene (BHT) and vitamin $\mathrm{C}$.

reported that the DPPH antioxidant activity in pandan extract were comparable with those obtained by Higher antioxidant potential was observed in both DPPH scavenging assay $(E C=48.350 \pm 0.002 \mu \mathrm{g} / \mathrm{mL})$ and reducing capacity $(\mathrm{OD}$ at $1000 \mu \mathrm{g} / \mathrm{mL}=0.787$ ) by the methanolic root extract than by the aqueous extract. Marinova et al. [35] but higher than that of Odukoya et al. [36]. When a comparison betweeen Figures 3 and 4 was made to appear the trend for ferric ions reducing activities of the pandan did not vary markedly from their DPPH free radical scavenging activities. Antioxidant compounds such as polyphenols may be more efficient reducing agents for ferric iron but some may not scavenge DPPH free radicals as efficiently due to steric hindrance [36].

Pulido et al. [37] reported that, in general, the ferric ion reducing ability of antioxidants correlates with the results from other methods used to estimate antioxidant capacity. Reducing DPPH radicals were also able to reduce ferric ions. Arnous et al. [38] reported a strong correlation between DPPH free radical scavenging ability and ferric ion reducing ability in wines.

\section{Anticancer activity}

The preliminary screening showed pandan extracts from 3 locations possessed anticancer promoting activity against MCF-7, with $78.3 \% 70.5 \%$ and 67.4 inhibition rate, respectively. Maximum MCF-7cell line inhibition was observed in pandan extract with values of $66.3 \%$ from Bachok location (Figure 4). MCF-7 cell lines treated with tamoxifen (positive control) showed 92.5\% inhibition at the same concentration. According to obtained results, at a concentration of $160 \mu \mathrm{g} / \mathrm{ml}$, however, pandan extracts from Bachok locations exhibited $\mathrm{IC}_{50}$ towards MCF-7 cells. The $\mathrm{IC}_{50}$ values of pandan extract from Bachok, Klang and Pontian locations against MCF-7 cells were 210.4, 285.6.6 and $334.2 \mu \mathrm{g} / \mathrm{mL}$, respectively. Our finding is consistent with Zan et al. [39] who is reported $\mathrm{IC}_{50}$ 


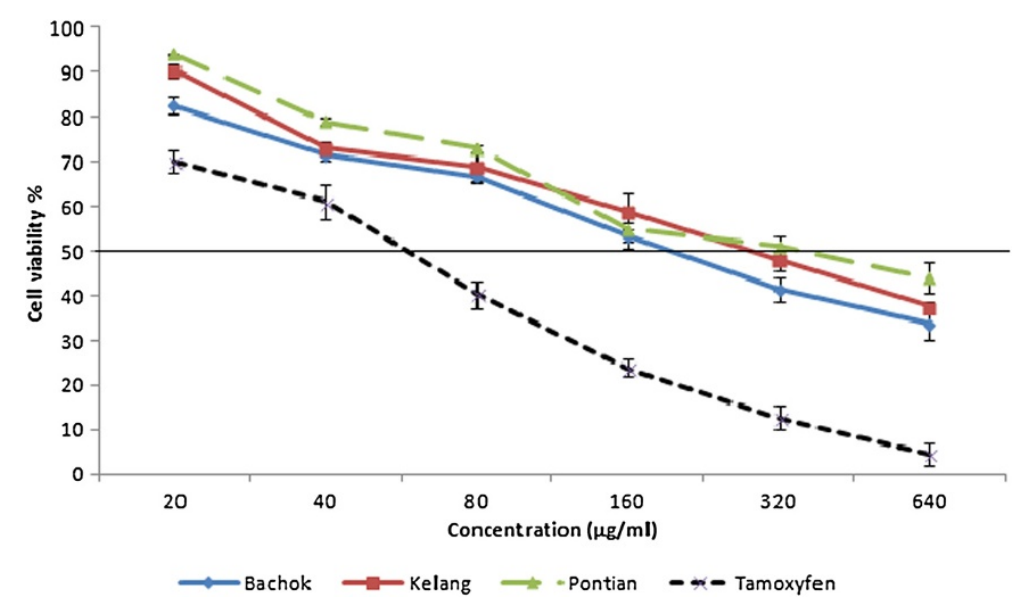

Figure 4 Dose-dependent anticancer of pandan extracts from 3 different locations (Bachok, Klang and Pontian) towards MCF-7 cell line as determined by the MTT assay.

value for $P$. amaryllifolius extract against breast cancer cell line obtain in $>100 \mu \mathrm{g} / \mathrm{mL}$. Flavonoids are among the best candidates for mediating the protective effect of diets rich in fruits and vegetables with respect to colorectal cancer [40]. Hence, flavonoid compounds could probably be responsible for the anticancer activity of curry leaf. Meanwhile, with the increase of extracts concentration, however, normal cell viability decreased in all extracts. In terms of toxicity to the normal cells (MCF-10A), $P$. amaryllifolius extracts from different locations were considered as not toxic as the $\mathrm{IC}_{50}$ values were greater than $640 \mu \mathrm{g} / \mathrm{ml}$ (Figure 5). In pandan extract from Bachok location at concentration of $210.4 \mu \mathrm{g} / \mathrm{ml}\left(\mathrm{IC}_{50}\right)$ the normal cell viability was recorded about $78 \%$. P. amaryllifolius extract was found to display selective antiproliferative activity against non hormone dependent breast cancer cells [39]. In other study, ethanol extract of $P$. amaryllifolius induced apoptosis on hormone independent breast cancer cell line MDA-MB-231 [41]. In the current study the highest values of flavonoid compounds were detected in pandan extract from Bachok location. Meanwhile, the highest anticancer activity against MCF-7 cell lines has been observed with extracts of pandan from Bachok location. This suggests that high anticancer activity in pandan extract may be attributed to the high concentrations of potent anticancer components such as rutin, epicatechin, kaempferol and gallic acid. However, more research needs to be undertaken before the association between these flavonoids and anticancer activity in curry leaf is more clearly understood.

\section{Conclusion}

In this study between three studied locations, the samples collected from the North (Bachok) which had a high

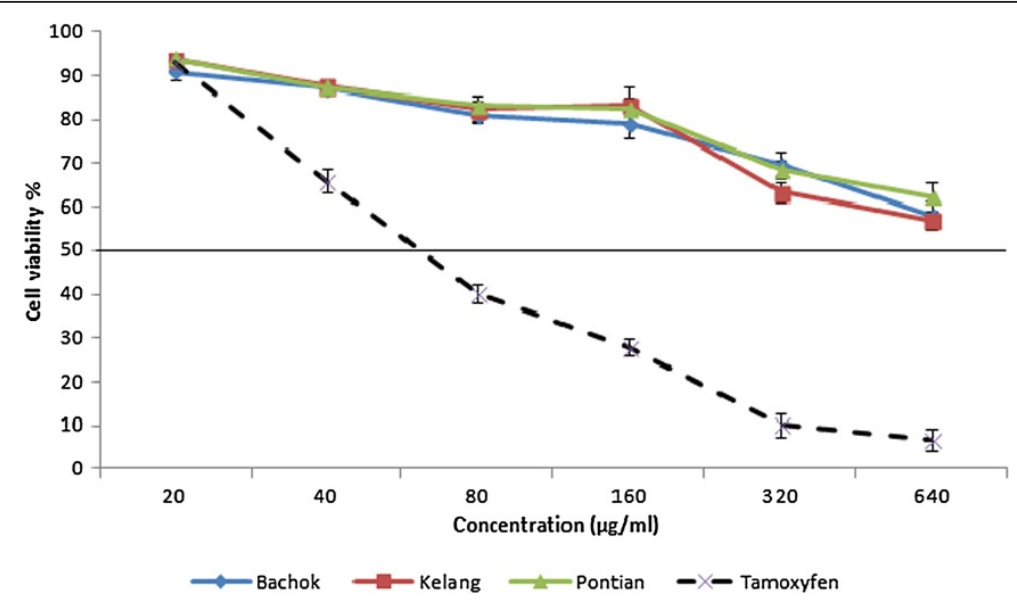

Figure 5 Effect of pandan extracts from three different locations (Bachok, Klang and Pontian) on normal cell (MCF-10A) viability. 
content of phenolic acids (specially gallic acid) and flavonoids (specially catechin and kaempferol), had a very high antioxidant scavenging value in both FRAP and DPPH assay. Conversely, the samples collected from the Southern portion (Pontian) appeared to have the lowest content of TP, TF and antioxidant activity. Recently several plant derived natural compounds have been screened for their anticancer activity in order to identify putative compounds with novel structures or mechanism of action. In current study pandan extracts showed good potential of bioactive compounds such as catechin, gallic acid, kaempferol and naringin. It can be concluded that these bioactive compounds present in pandan extracts work synergistically in inhibiting proliferation of breast cancer cells and suggests that they may have potential for use as a natural additive in human diets. The wide ranges of the secondary metabolites content and antioxidant activities of pandan extracts could be due to many factors including locations, altitude, temperature, age of plant, climate and variation of plant variety. The ranges of phenolic acids and flavonoid content and antioxidant activity will be useful for standardization of pandan extracts for further pharmaceutical productions. These results also show the possibility of increasing the content of natural antioxidants by optimizing the growing conditions of pandan. More information on other bioactive component of pandan would help us to establish a greater degree of accuracy on this matter.

\section{Competing interests}

The authors declare that they have no competing interests.

\section{Authors' contributions}

Experimental work was done by AG under the supervision of $\mathrm{HJ}$ (post doctoral project). The first draft of the paper was written by AG and reviewed by HJ. Both authors read and approved the final manuscript.

\section{Acknowledgements \\ The authors would like to thank the Ministry of Higher Education Malaysia, and the Research Management Centre, University Putra Malaysia (UPM) for sponsoring this work. Authors also are grateful to the Mr. Thiyagu Devarajan and Malaysian Agriculture Research and Development Institute for collecting of plant samples. The authors would like to acknowledge Prof. Dr Asmah Rahmat and all staff of laboratory of nutrition, department of nutrition and dietetics, faculty of medicine and health sciences for all the helps and guidance in order to accomplish this project.}

Received: 3 June 2013 Accepted: 21 November 2013 Published: 1 December 2013

\section{References}

1. Lane AL, Kubanek J: Secondary Metabolite Defenses Against Pathogens and Biofoulers. In Algal Chemical Ecology. Edited by Amsler CD. Berlin: Springer-Verlag Press; 2008:229-243.

2. Booker FL: Influence of carbon dioxide enrichment, ozone and nitrogen fertilization on cotton (Gossypium hirsutum L.) leaf and root composition. Plant Cell Environ 2000, 23:573-583.

3. Karimi E, Jaafar HZE, Ahmad S: Phytochemical analysis and antimicrobial activities of methanolic extracts of leaf, stem and root from different varieties of Labisa pumila Benth. Molecules 2011, 16:4438-4450.
4. Park SJ, Myoung H, Kim YY, Paeng JY, Park JW, Kim MJ, Hong SM: Anticancer effects of genistein, green tea catechins, and cordycepin on oral squamous cell carcinoma. J Korean Oral Maxillofac Surg 2008, 34:1-10.

5. Ghasemzadeh A, Jaafar HZE: Antioxidant potential and anticancer activity of Malaysian young ginger (Zingiber officinale Roscoe) varieties grown under different $\mathrm{CO}_{2}$ concentration. J Medicplants Res 2011, 5(14):3247-3255

6. Atoui K, Mansouri A, Bosku G, Kefalas P: Tea and herbal infusions: their antioxidant activity and phenolic profile. Food Chem 2005, 89:27-36.

7. Lafuente AG, Guillamon E, Villares A, Rostagno MA, Martínez JA: Flavonoids as anti-inflammatory agents: implications in cancer and cardiovascular disease. Infla Res 2009, 58:537-552.

8. Shukla Y, Prasad S, Tripathi C, Singh M, George J, Kalra N: In vitro and in vivo modulation of testosterone mediated alterations in apoptosis related proteins by [6]-gingerol. Mol Nutr Food Res 2007, 51:1492-1502.

9. Arts IC, Jacobs DRJ, Gross M, Harnack LJ, Folsom AR: Dietary catechins and cancer incidence among postmenopausal women: the lowa Women's Health Study (United States). Cancer Cause Control 2002, 13:373-382.

10. Davis W, Lamson MS, Matthew S, Brignall ND: Antioxidants and cancer III: quercetin. Altern Med Rev 2000, 5:196-208

11. Wongpornchai S, Pandan W, Peter KV (Eds): Handbook of Herbs and Spices. England: Publishing Limited and CRC Press LLC; 2006:453-459.

12. Wakte KV, Nadaf AB, Krishnan S, Thengane RJ: Studies on lower epidermal papillae, the site of storage of basmati rice aroma compounds in Pandanus amaryllifolius Roxb. Curr Sci 2007, 93(2):238-242.

13. Loh SK, Che Man Y, Tan CP, Osman A, Hamid NSA: Process optimization of encapsulated pandan (Pandanus amaryllifolius) powder using spray drying method. J of the Sci of Food and Agri 2005, 85:1999-2004.

14. Zhao X, Carey EE, Wang W, Rajashekar CB: Does organic production enhance phytochemical content of fruit and vegetables? Current knowledge and prospects for research. Hort Technology 2006, 16:1-8.

15. Crozier A, Jensen E, Lean MEJ, Mc Donald MS: Quantitative analysis of flavonoids by reversed-phase high performance liquid chromatography. J Chromatogr 1997, 761:315-321.

16. Bushra S, Farooq A, Muhammad A: Effect of extraction solvent/technique on the antioxidant activity of selected medicinal plant extracts. Molecules 2009, 14:2167-2180.

17. Wang TC, Chuang YC, Ku YH: Quantification of bioactive compounds in citrus fruits cultivated in Taiwan. Food Chem 2007, 102:1163-1171.

18. Standard Operating Protocol: HPLC Analysis of Phenolic acids (SOP), SOP No.: CB0103. West Lafayette, IN, USA: Botanical Center for Age-Related Diseases; 2001:9.

19. Kim DO, Padilla-Zakour OI, Griffiths PD: Flavonoids and antioxidant capacity of various cabbage genotypes at juvenile stage. J Food Sci 2004, 69:685-689.

20. Benzie IFF, Strain JJ: The ferric reducing ability of plasma (FRAP) as a measure of antioxidant power: the FRAP assay. Anal Biochem 1996, 239:70-76.

21. Mensor LL, Menezes FS, Leitao GG, Reis AS, Santos TS, Coube CS: Screening of Brazilian plant extracts for antioxidant activity by the use of DPPH free radical method. Phytother Res 2001, 15:127-130

22. Lau CS, Ho CY, Kim CF, Leung KN, Fung KP, Tse TF, Chan HL, Chow MS: Cytotoxic activities of Coriolus versicolor (Yunzhi) extract on human leukemia and lymphoma cells by induction of apoptosis. Life Sci 2004, 75:797-808

23. Wang SY: Antioxidant capacity of berry crops, culinary herbs and medicinal herbs. Acta Horticulare 2003, 620:461-473.

24. Tolonen M, Taipale M, Viander B, Pihlava JM, Korhonen H, Ryhänen EL: Plant derived biomolecules in fermented cabbage. J Agr Food Chem 2002, 50:6798-6803

25. Kim DO, Lee CY: Comprehensive study on vitamin C equivalent antioxidant capacity (VCEAC) of various polyphenolics in scavenging a free radical and its structural relationship. Crit Rev Food Science and Nut 2004, 44(4):253-273.

26. Zhang M, Hettiarachchy SN, Horax R, Kannan A, Praisoody MDA, Muhundan A, Mallangi CR: Phytochemicals, antioxidant and antimicrobial activity of Hibiscus sabdariffa, Centella asiatica, Moringa oleifera and Murraya koenigii leaves. J of Med Plants Res 2011, 5:6672-6680.

27. Miean KH, Mohamed S: Flavonoid (Myricetin, Quercetin, Kaempferol, Luteolin, and Apigenin) Content of Edible Tropical Plants. J Agric Food Chem 2001, 49:3106-3112. 
28. Wojdyło A, Oszmian'ski J, Czemerys R: Antioxidant activity and phenolic compounds in 32 selected herbs. Food Chem 2007, 105:940-949.

29. Wu X, Beecher GR, Holden JM, Haytowitz DB, Gebhardt SE, Prior RL: Lipophilic and hydrophilic antioxidant capacities of common foods in the United States. J Agri and Food Chem 2004, 52:4026-4037.

30. Luximon-Ramma A, Bahorun T, Soobrattee AM, Aruoma Ol: Antioxidant activities of phenolic, proanthocyanidin and flavonoid components in extracts of Acacia fistula. J Agric Food Chem 2005, 50:5042-5047.

31. Ghasemzadeh A, Jaafar HZE, Karimi E, Ibrahim MH: Combined effect of $\mathrm{CO}_{2}$ enrichment and foliar application of Salicylic acid on anthocyanin, flavonoids and isoflavonoids production and their antioxidant activity in ginger. BMC Comp and Alte Med 2012, 12:229.

32. Wong CC, Li HB, Cheng KW, Chen F: A systematic survey of antioxidant activity of Chinese medicinal plants using the ferric reducing antioxidant power assay. Food Chem 2006, 97:705-711.

33. Bors W, Heller W, Michael C, Saran M: Radical chemistry of flavonoids antioxidants. Adv Exp Med Biol 1990, 264:165-170

34. Sasikumar JM, Jinu U, Shamna R: Antioxidant Activity and HPTLC Analysis of Pandanus odoratissimus L. Root. Eur J of Bio Sci 2009, 1(2):17-22.

35. Marinova D, Ribarova F, Atanassova M: Total phenolics and total flavonoids in Bulgaria fruits and vegetables. J Univ Chem Technol Metallurgy 2005, 40:255-260.

36. Odukoya OA, Inya-Agba SI, Segun FI, Sofidiya MO, llori O: Antioxidant activity of selected Nigerian green leafy vegetables. Am J Food Technol 2007, 2:169-175

37. Pulido R, Bravo L, Saura-Calixto F: Antioxidant activity of dietary polyphenols as determined by a modified ferric reducing/antioxidant power assay. J of Agr Food Chem 2000, 48:3396-3402.

38. Arnous A, Makris DP, Kefalas P: Correlation of pigment and flavanol content with antioxidant properties in selected aged regional wines from Greece. J of Food Component and Anal 2000, 15:655-665.

39. Zan C, Rahmat A, Akim AM, Alitheen NBM, Othman F, Lian GEC: Anti-proliferative effects of pandan leaves (Pandanus amarylfolius), kantan flower (Etlingera elatior) and turmeric leaves (Curcuma longa). Nut Food Sci 2011, 41(4):238-241.

40. Ghasemzadeh A, Jaafar HZE, Karimi E: Involvement of salicylic acid on antioxidant and anticancer properties, anthocyanin production and chalcone synthase activity in ginger (Zingiber officinale Roscoe) Varieties. Int J Mol Sci 2012, 13:14828-14844.

41. Chong HZ, Yeap SK, Rahmat A, Akim AM, Alitheen NB, Othman F, Gwendoline-Ee CL: In vitro evaluation of Pandanus amaryllifolius ethanol extract for induction of cell death on non-hormone dependent human breast adenocarcinoma MDA-MB-231 cell via apoptosis. BMC Compl Alter Med 2012, 12:134.

doi:10.1186/1472-6882-13-341

Cite this article as: Ghasemzadeh and Jaafar: Profiling of phenolic compounds and their antioxidant and anticancer activities in pandan (Pandanus amaryllifolius Roxb.) extracts from different locations of Malaysia. BMC Complementary and Alternative Medicine 2013 13:341.

\section{Submit your next manuscript to BioMed Central and take full advantage of:}

- Convenient online submission

- Thorough peer review

- No space constraints or color figure charges

- Immediate publication on acceptance

- Inclusion in PubMed, CAS, Scopus and Google Scholar

- Research which is freely available for redistribution

Submit your manuscript at www.biomedcentral.com/submit
Ciomed Central 